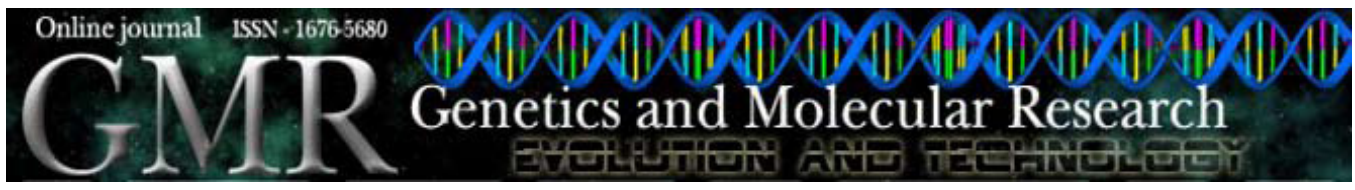

\title{
Expression of acid phosphatase in the seminiferous epithelium of vertebrates
}

\author{
R.L. Peruquetti, S.R. Taboga and M.T.V. Azeredo-Oliveira \\ Departamento de Biologia, Instituto de Biociências, Letras e Ciências Exatas, \\ Universidade Estadual Paulista, São José do Rio Preto, SP, Brasil \\ Corresponding author: M.T.V. Azeredo-Oliveira \\ E-mail: tercilia@ibilce.unesp.br
}

Genet. Mol. Res. 9 (2): 620-628 (2010)

Received December 22, 2009

Accepted January 17, 2010

Published April 6, 2010

DOI 10.4238/vol9-2gmr730

\begin{abstract}
Acid phosphatases (AcPs) are known to provide phosphate to tissues that have high energy requirements, especially during development, growth and maturation. During spermatogenesis AcP activity is manifested in heterophagous lysosomes of Sertoli cells. This phagocytic function appears to be hormone-independent. We examined the expression pattern of AcP during the reproductive period of four species belonging to different vertebrate groups: Tilapia rendalli (Teleostei, Cichlidae), Dendropsophus minutus (Amphibia, Anura), Meriones unguiculatus (Mammalia, Rodentia), and Oryctolagus cuniculus (Mammalia, Lagomorpha). To demonstrate AcP activity, cryosections were processed for enzyme histochemistry by a modification of the method of Gömöri. AcP activity was similar in the testes of these four species. Testes of T. rendalli, D. minutus and $M$. unguiculatus showed an intense reaction in the Sertoli cell region. AcP activity was detected in the testes of D. minutus and O. cuniculus in seminiferous epithelium regions, where cells are found in more advanced stages of development. The seminiferous epithelium of all
\end{abstract}


four species exhibited AcP activity, mainly in the cytoplasm of either Sertoli cells or germ cells. These findings reinforce the importance of AcP activity during the spermatogenesis process in vertebrates.

Key words: Acid phosphatase; Reproduction; Testis; Spermatogenesis; Vertebrates

\section{INTRODUCTION}

Acid phosphatases (AcPs) are known to provide phosphate to tissues that show high energy requirements, especially during development, growth and maturation (Blum, 1970; Hurkadli et al., 1985). They are ubiquitous enzymes that catalyze the hydrolysis of orthophosphate monoesters under acidic conditions. Despite a common functional identity, these hydrolases can be differentiated according to structural, catalytic and immunological properties, as well as tissue distribution and subcellular location (Suter et al., 2001).

Five important forms of AcPs are found in humans: prostatic, lysosomal, erythrocytic, macrophagic, and osteoclastic (Bull et al., 2002). These forms were detected in erythrocytes, leukocytes, platelets, liver, spleen, kidney, bone, and other tissues (Saftig et al., 1997; Cerri et al., 1999; Bull et al., 2002). The expression of this enzyme also has been studied in the testis. It is well known that AcP activity is present in the lysosomes of Sertoli cells, which have a heterophagic function (Niemi and Kormano, 1965; Hurk et al., 1974; Chemes, 1986; Porawski et al., 2004). In rats, the digestion of residual bodies is likely to begin with autophagy in spermatids and be completed with phagocytosis by Sertoli cells. This phagocytic function appears to be hormone-independent (Chemes, 1986). This fact is corroborated by the conclusions of some studies in which some species including Oreochromis niloticus (Teleostei, Cichlidae) and Odonthestes perugiae (Teleostei, Atherinidae) showed AcP expression in the non-reproductive period (Porawski et al., 2004), whereas in other species such as Liolemus elongatus (Reptile, Squamata) AcP activity was detected only in the reproductive period (Grimalt et al., 1995).

Thus, the present study aimed to detect the expression pattern of the acid phosphatase in the reproductive period of four species belonging to different vertebrate groups: Tilapia rendalli (Teleostei, Cichlidae); Dendropsophus minutus (Amphibia, Anura), Meriones unguiculatus (Mammalia, Rodentia), and Oryctolagus cuniculus (Mammalia, Lagomorpha). These species were chosen because they are very useful and important models for reproduction studies in some Brazilian regions, since they are easily collected in the field (D. minutus) or widely raised in captivity (T. rendalli, M. unguiculatus and O. cuniculus) (Peruquetti, 2009). We expected to find AcP activity in the seminiferous epithelium of each species studied reinforcing the importance of this enzyme during the the spermatogenesis process in vertebrates.

\section{MATERIAL AND METHODS}

Five adult male specimens of T. rendalli (Teleostei, Cichlidae) taken from fish farming tanks of the São Paulo State University (UNESP/IBILCE), São José do Rio Preto, SP, Brazil, were housed in asbestos tanks (500 L, 1 fish, 5L-1) for 15 days before experimentation. Water 
was kept at $25^{\circ} \mathrm{C}$ and light at 12-h dark:light cycle (from 7:00 to 19:00 h) and constant aeration was supplied. Fish were fed pellets for tropical fish (28\% protein) offered ad libitum $1 \mathrm{~h}$ after starting the light period and $1 \mathrm{~h}$ before ending the light period. The animals were killed by excess anesthesia (benzocaine) and their gonads were removed. Fifteen adult males in calling activities of D. minutus (Amphibia, Anura) were captured at the Morro do Diabo State Park (Municipality of Teodoro Sampaio, State of São Paulo, Brazil) during nocturnal field work, acclimatized in plastic bags, and transported to the laboratory. The amphibians were anesthetized and killed by ether inhalation, and their gonads were removed. Five adult male specimens of $M$. unguiculatus (Mammalia, Rodentia) were obtained from the Biology Department Animal House (IBILCE/ UNESP). Five adult male specimens of $O$. cuniculus (Mammalia, Lagomorpha) were obtained from the FAMERP Animal House (São José do Rio Preto School of Medicine, São José do Rio Preto, SP, Brazil). These animals were housed under standard conventional conditions $\left(25^{\circ} \mathrm{C}, 40-\right.$ $70 \%$ relative humidity, 12-h light/dark cycle) and allowed access to chow and water ad libitum. The animals were anesthetized and killed by carbon dioxide gas $\left(\mathrm{CO}_{2}\right)$ inhalation and their gonads were removed. All animals were obtained during their respective reproductive periods (Figure 1). This study followed the ethical principles of animal research adopted by the Brazilian College of Animal Experimentation (COBEA) and was approved by the Biosciences Institute/UNESP Animal Research Ethics Committee (CEEA) under protocol number 054/06. The animals were treated according to the recommendations of the Committee on Care and Use of Laboratory Animals (1980) from the Institute of Laboratory Animal Resources. All sacrifice procedures were in accordance with Resolution 714 - Brazilian Veterinary Medicine Federal Council.

\begin{tabular}{|c|c|c|c|c|c|c|c|c|c|c|c|c|}
\hline \multicolumn{13}{|c|}{ REPRODUCTIVE PERIOD } \\
\hline Species & $\mathbf{J}$ & $\mathbf{F}$ & $\mathbf{M}$ & $\mathbf{A}$ & $\begin{array}{l}\mathrm{M} \cdot \mathrm{J} \\
\end{array}$ & $\mathrm{J}$ & & & & $\overline{\mathbf{O}}$ & & $\mathbf{D}$ \\
\hline Tilapia rendalli & & & & & & & & & & & & \\
\hline Dendropsophus minutus & & & & & & & & & & & & \\
\hline Meriones unguiculatus & & & & & & & & & & & & \\
\hline Oryctolagus cuniculus & & & & & & & & & & & & \\
\hline
\end{tabular}

Figure 1. Reproductive periods of the four species studied. The open squares indicate the non-reproductive period of each species, the light gray squares demonstrate the reproductive period of each species, and the striped squares show the months during which each species was collected.

\section{Hematoxylin-eosin stain}

The testes of each animal were removed and fixed by immersion in Bouin's fixative solution for $24 \mathrm{~h}$. The testes were embedded in glycol-methacrylate historesin. Sections (1 to 3 $\mu \mathrm{m}$ thick) were obtained using a Leica RM 2155 microtome. Tissue sections were submitted to hematoxylin-eosin staining according to Ribeiro and Lima (2000). The sections of seminiferous tubules were evaluated with an Olympus BX 60 photomicroscope and documented by Image Pro-Plus-Media Cybernetics, version 6.1, for the Windows computer software for image analysis. 


\section{Acid phosphatase technique}

The testes were removed after sacrifice and immediately frozen in liquid nitrogen and sectioned (10 to $15 \mu \mathrm{M}$ ) in a Leica CM 1850 cryostat microtome. For demonstration of AcP activity, the cryosections were processed for enzyme histochemistry by a modification of the method of Gömöri (1950). Frozen sections were incubated for $60 \mathrm{~min}$ at $37^{\circ} \mathrm{C}$ in a medium composed of sodium $\beta$-glycerophosphate substrate and lead nitrate. The control for the histochemical reaction was obtained using the incubation medium without substrate (ß-glycerophosphate). After incubation, the sections were washed in distilled water, treated with $1 \%$ ammonium sulfide for 1 min, rinsed in distilled water and then counterstained with $0.1 \%$ methyl-green aqueous solution for $10 \mathrm{~min}$. Forty sections of seminiferous epithelium containing experimental reactions and 40 sections of seminiferous epithelium containing control reactions from each species studied were evaluated with an Olympus BX 60 photomicroscope and documented by Image Pro-Plus-Media Cybernetics, version 6.1, for the Windows computer software for image analysis.

\section{RESULTS}

The hematoxylin-eosin-staining technique was employed for specific analysis of seminiferous epithelium structure and for general analysis of seminiferous epithelium. This general analysis effectively located the sites of AcP action in the testes of each animal studied. In $T$. rendalli, Sertoli cells surround germ cells in the same developmental stage, forming germ cysts, and this species has an unrestricted type of testicular arrangement, in which spermatogonias appear along the length of the tubules (Figure 2A). In D. minutus, Sertoli cells also surround germ cells to form germ cysts, although spermatogonias appear in cysts instead of along the tubule length (Figure 2D). In M. unguiculatus and O. cuniculus, the germ cells were found at different levels from the base of the tubule to the lumen and are surrounded by Sertoli cell cytoplasm (Figure $2 \mathrm{G}$ and $\mathrm{J}$ ). This Sertoli cell cytoplasm extends the entire height of the epithelium because the cell serves to nurture the germ cells through their development cycles. As the germ cells divide and develop into different cell types, they move from the basement membrane region through the tight junctional complex of adjacent Sertoli cells until they reach the adluminal compartment. Synchrony of germ cell development results in large areas of the seminiferous tubule containing vast numbers of cells at the same level of development, the same stage of spermatogenesis. This sequential order of stages and their repetition along the length of the tubules constitutes the "wave" of spermatogenesis in mammalian seminiferous epithelium.

The testes of $T$. rendalli submitted to the experimental reaction (incubation medium with sodium $\beta$-glycerophosphate) showed an intense AcP activity at the base of the seminiferous epithelium and at the base of the germ cysts, where the Sertoli cells are located (Figure 2B). This activity was moderate or absent in the lumens of both seminiferous epithelium and germ cysts (Figure 2B). AcP activity was detected predominantly in the cytoplasm and not in the nuclear interior. The testes of $T$. rendalli submitted to the control reaction (incubation medium without sodium $\beta$-glycerophosphate) did not display enzymatic activity either at the base of seminiferous tubules and germ cysts or inside these structures (Figure 2C). The testes of $D$. minutus submitted to the experimental reaction showed AcP activity at the base of both seminiferous epithelium and germ cysts where the Sertoli cells are located (Figure 2E) and in the germ cysts with cells in more advanced stages of development (later spermatids and spermatozoa) 

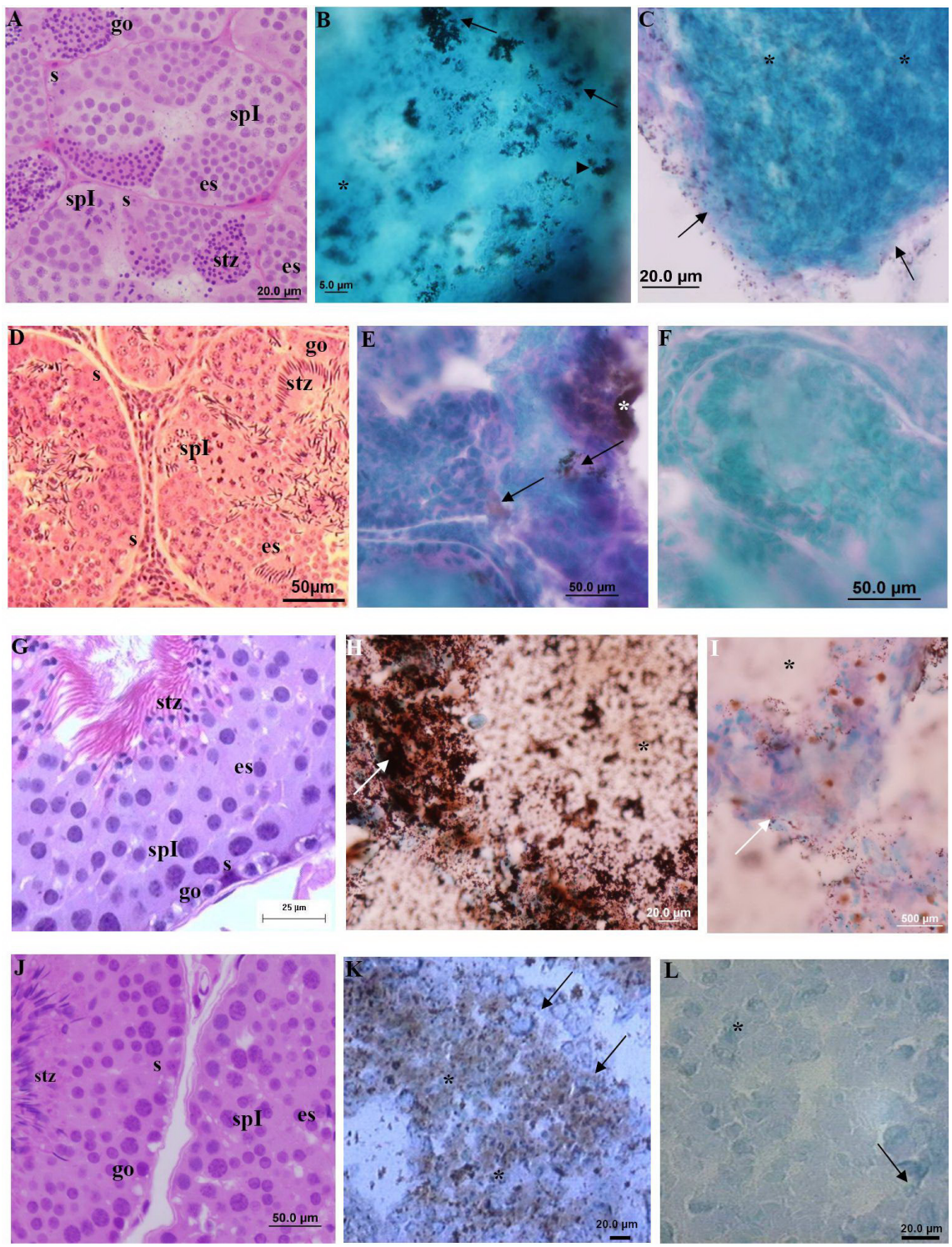

Figure 2. A. to C. Tilapia rendalli germ epithelium; D. to F. Dendropsophus minutus germ epithelium; G. to I. Meriones unguiculatus seminiferous tubules; J. to L. Oryctolagus cuniculus seminiferous tubules. A, D, G, and $\mathrm{J}$ : Hematoxylin-eosin stain. General analysis of the germ epithelium: go = spermatogonium; spI = primary spermatocyte; es = spermatids; $\mathrm{stz}=$ spermatozoon; $\mathrm{s}=$ Sertolli cells. B, E, H, and K: Detection of acid phosphatase (AcP) activity (experimental reaction). Arrows: Base of germ epithelium, base of germ cysts or base of seminiferous tubules. Asterisk: Lumen of germ epithelium, lumen of germ cysts or lumen of seminiferous tubules. B: AcP activity in germ cell cytoplasm (arrowhead). C, F, I, and L: Detection of AcP activity (control reaction). Arrows: Base of germ epithelium, base of germ cysts or base of seminiferous tubules. Asterisk: Lumen of germ epithelium, lumen of germ cysts or lumen of seminiferous tubules. 
(Figure 2E). The D. minutus testes submitted to the control reaction showed a total absence of enzyme activity at the base of the seminiferous tubules and germ cysts as in the interior of these structures (Figure 2F). The testes of $M$. unguiculatus submitted to the experimental reaction exhibited intense AcP activity at the seminiferous tubule base, the location of the Sertoli cells (Figure 2H). This activity was moderate in the seminiferous tubule lumen (Figure 2H). AcP activity was detected predominantly in the cytoplasm and not in the nuclear interior. Testes of $M$. unguiculatus submitted to the control reaction showed no enzymatic activity either at the base or in the lumen of seminiferous tubules (Figure 2I). The O. cuniculus testes submitted to the experimental reaction displayed AcP activity throughout the seminiferous epithelium; however, in the lumen this reaction was more intense (Figure $2 \mathrm{~K}$ ). Testes of $O$. cuniculus submitted to the control reaction showed a total absence of enzyme activity both at the base and in the lumen of the seminiferous tubules (Figure 2L). The main results of this study are summarized Table 1 .

\begin{tabular}{|c|c|c|c|c|c|}
\hline \multirow[t]{2}{*}{ Reaction } & \multirow[t]{2}{*}{ Germ epithelium position } & \multicolumn{4}{|c|}{ Species } \\
\hline & & T. rendalli & D. minutus & M. unguiculatus & O. cuniculus \\
\hline \multirow{2}{*}{$\begin{array}{l}\text { Experimental } \\
\text { (with sodium } \beta \text {-glycerophosphate) }\end{array}$} & Base (Sertoli cells) & ++ & ++ & ++ & + \\
\hline & $\begin{array}{l}\text { Lumen } \\
\text { (later spermatids } \\
\text { and spermatozoon) }\end{array}$ & + & ++ & + & ++ \\
\hline \multirow{2}{*}{$\begin{array}{l}\text { Control } \\
\text { (without sodium } \beta \text {-glycerophosphate) }\end{array}$} & Base (Sertoli cells) & - & - & - & - \\
\hline & $\begin{array}{l}\text { Lumen } \\
\text { (later spermatids } \\
\text { and spermatozoon) }\end{array}$ & - & - & - & - \\
\hline
\end{tabular}

\section{DISCUSSION}

The Gömöri method has been widely used for identification of AcP activity in different tissues and diagnosis of lesions (Sternberg, 1996; Zaviacic, 1999). AcPs are ubiquitous enzymes that catalyze the hydrolysis of orthophosphate monoesters under acidic conditions (Suter et al., 2001). AcP activity has been demonstrated in the liver of rats (Siebert, 1966), nucleoli of human cells (Soriano and Love, 1971), Allium cepa (Sánchez-Pina et al., 1980), maize roots (Deltour et al., 1981), salivary glands of Drosophila melanogaster (Jones and Bowen, 1993), gerbil (M. unguiculatus) prostate glands of both sexes (Custódio et al., 2004), and salivary glands of Triatomines (Anhê et al., 2007) and during spermiogenesis of insects (Báo and Dolder, 1990; Fernandes, 1999).

In the present study, AcP activity was demonstrated in the seminiferous epithelium during the reproductive period of four vertebrate species. AcP activity was similar in the testes of these four species studied, all of which were in their respective reproductive periods. According to Porawski et al. (2004) in Nile tilapia (O. niloticus) and kingfish (Odonthestes perugiae), positive AcP activity was observed only in the non-reproductive period: winter (Nile tilapia) and summer (kingfish). This difference can be related to hormonal control of AcP expression in these organs. Acid hydrolases in lizard epidymis showed distinct activity in the reproductive cycle. Acid hydrolytic activity was intense in the non-reproductive period of Phymaturus palluma. However, in another 
lizard species, Liolemus elongatus, the activity of acid hydrolases was intense in the reproductive period (Grimalt et al., 1995). These authors postulated that the epididymal acid hydrolases may be under hormonal control in the lizards studied. On the other hand, AcP activity is not hormonedependent in rats (Chemes, 1986) and the human testicular AcP gene was found to be upregulated by androgens and downregulated by estrogen (Yousef et al., 2001). In spite of these observations, it had been postulated that, in general, AcP activity is very important to the spermatogenetic process in vertebrates during the reproductive period as much as in the non-reproductive period. In germ cells during the reproductive period of some animals, the study of acid phosphatase has been principally related to the lysosomes of Sertoli cells (Niemi and Kormano, 1965; Hurk et al., 1974; Chemes, 1986; Porawski et al., 2004), the acrosome (Anderson, 1968; Sousa et al., 1988; Báo et al., 1989) and the axoneme (Anderson, 1968; Baccetti et al., 1971, 1973).

Testes of $T$. rendalli, D. minutus and M. unguiculatus showed an intense reaction in the Sertoli cell region. This finding indicates a prominent/significant autophagic function of this cell type in this tissue during the reproductive period in these species. It is well known that AcP activity is present in heterophagic lysosomes of Sertoli cells (Niemi and Kormano, 1965; Hurk et al., 1974; Chemes, 1986; Porawski et al., 2004). AcP and lysosomal contents of Sertoli cells are greater than those of germ cells, and the residual body disposal is probably initiated by autophagy and completed by Sertoli cell phagocytosis (Chemes, 1986). In the present study, intense AcP activity was detected in testes of D. minutus and $O$. cuniculus in regions of the seminiferous epithelium where cells were found in more advanced stages of development: germ cysts of later spermatids and spermatozoa (D. minutus) and lumen of the seminiferous tubules $(O$. cuniculus). These findings indicate that the Sertoli cell lysosomes had started to act in testes of these species by assisting in the digestion of residual bodies and cytoplasmic remains in these seminiferous-tubule regions and that $\mathrm{AcP}$ activity is present during acrosome and axoneme formation. It is well known that AcP activity - present in spermatogonial cells, primary and secondary spermatocytes, spermatids and spermatozoon bundles - may readily provide phosphate to meet their high energy requirements (Blum, 1970; Hurkadli et al., 1985).

The seminiferous epithelium in all the species studied showed AcP activity, mainly in the cytoplasm of either Sertoli cells or germ cells. This finding reflects a strong relation between AcP activity and lysosomes in testicular cells. In some somatic organs including salivary glands of Triatomines a role for acid phosphatase in the nuclear matrix could be assumed, because $\mathrm{AcP}$ was detected in both the nucleolus and chromatin. Thus, phosphatase activity during rRNA transcription, possibly in the nucleolar fibrillar center, is suggested (Anhê et al., 2007). However, it is impossible to conclude that AcP is not present in the nucleus of some germ cell epithelium, since at some sites of the organ the reaction was so intense that it hid the cell nuclei.

In conclusion all species studied showed AcP activity expressed in the testes during their respective reproductive periods. This activity presented was partially distinct among the four species and was detected mainly in the cytoplasm of the cells. These findings reinforce the importance of AcP activity during the spermatogenesis process of vertebrates.

\section{ACKNOWLEDGMENTS}

Special thanks go to Mr. Luiz Roberto Faleiros Jr. at the Laboratory of Microscopy and Microanalysis for help with laboratory techniques. The authors are also grateful to Dr. Tiago da Silveira Vasconcelos and Dr. Tiago Gomes dos Santos for assistance in the collection of amphibians 
and to Dr. Thais Billalba de Carvalho, MSc. Roselene Silva Costa Ferreira and Mr. Carlos Eduardo Sousa for assistance with fish collection. R.L. Peruquetti, S.R. Taboga and M.T.V. Azeredo-Oliveira are indebted to FAPESP (São Paulo Research Foundation - Grant \#2007/04521-4) and CNPq (Brazilian Research Council - Grant \#141375/2006-0) for financial support and fellowships.

\section{REFERENCES}

Anderson WA (1968). Cytochemistry of sea urchin gametes. 3. Acid and alkaline phosphatase activity of spermatozoa and fertilization. J. Ultrastruct. Res. 25: 1-14.

Anhê AC, Lima-Oliveira AP and Azeredo-Oliveira MT (2007). Acid phosphatase activity distribution in salivary glands of triatomines (Heteroptera, Reduviidae, Triatominae). Genet. Mol. Res. 6: 197-205.

Baccetti B, Bigliardi E, Burrini AG and Rosati F (1971). Histochemical observation on the insect sperm cell by electron microscope. J. Ultrastruct. Res. 37: 248-249.

Baccetti B, Burrini AG, Dallai R, Giusti F, et al. (1973). Structure and function in the spermatozoon of Tenebrio molitor (the spermatozoon of Arthropoda. XX). J. Mechanochem. Cell Motil. 2: 149-161.

Báo SN and Dolder H (1990). Ultrastructural localization of acid phosphatase in spermatic cells of Ceratitis capitata (Diptera). Histochemistry 93: 439-442.

Báo SN, Quagio-Grassiotto I and Dolder H (1989). Acrosome formation in Ceratitis capitata (Diptera, Tephritidae). Cytobios 58: 93-100.

Blum MS (1970). Invertebrate Testis. In: The Testis (Johanson AD, Gomes WR and Vandemark NL, eds.). Academic Press, London, New York, 393-438.

Bull H, Murray PG, Thomas D, Fraser AM, et al. (2002). Acid phosphatases. Mol. Pathol. 55: 65-72.

Cerri LMO, Ajzen S, Arap S and Cerri GG (1999). Ultra-sonografia da Próstata. Sarvier, São Paulo.

Chemes H (1986). The phagocytic function of Sertoli cells: a morphological, biochemical, and endocrinological study of lysosomes and acid phosphatase localization in the rat testis. Endocrinology 119: 1673-1681.

Committee on Care and Use of Laboratory Animals (1980). Guide for the Care and Use of Laboratory Animals. National Research Council, Publication No. 96-03.

Custodio AM, Goes RM and Taboga SR (2004). Acid phosphatase activity in gerbil prostate: comparative study in male and female during postnatal development. Cell Biol. Int. 28: 335-344.

Deltour R, Fransolet S and Loppes R (1981). Inorganic phosphate accumulation and phosphatase activity in the nucleus of maize embryo root cells. J. Cell Sci. 47: 77-89.

Fernandes AP (1999). Ultrastructural localization of enzymatic activity during spermiogenesis in two phytophagous bugs (Hemiptera: Pentatomidae). Tissue Cell 31: 349-356.

Gömöri G (1950). An improved histochemical technique for acid phosphatase. Biotech. Histochem. 25: 81-85.

Grimalt PE, Castro LP, Mayorga LS and Bertini F (1995). Epididymal acid hydrolases in the annual reproductive cycle of two lizards. Comp. Biochem. Physiol. A Comp. Physiol. 112: 321-325.

Hurk R, Van Den Meek J and Peute J (1974). Ultrastructural study of the testis of the black molly (Mollienisia latipinna) I. The intratesticular efferent duct system. Proceedings of the Kon. Ned. Akad. Wetensch. Serie C 77, 460-469. Endocrinology 77: 5.

Hurkadli HK, Hooli MA and Nadkarni VB (1985). Acid phosphate activity in the testis of the Eri silkworm: Philosamia ricini (Hutt.) - A histochemical study. Curr. Sci. 54: 530-532.

Jones HE and Bowen ID (1993). Acid phosphatase activity in the larval salivary glands of developing Drosophila melanogaster. Cell Biol. Int. 17: 305-315.

Niemi M and Kormano M (1965). Cyclical changes in and significance of lipids and acid phosphatase activity in the seminiferous tubules of the rat testis. Anat. Rec. 151: 159-170.

Peruquetti RL (2009). Caracterização do Ciclo Nucleolar e da Formação do Corpo Cromatóide na Espermatogênese de Alguns Vertebrados. Doctoral thesis, Instituto de Biociências, Letras e Ciências Exatas UNESP/IBILCE, São José do Rio Preto.

Porawski M, Wassermann GF and Achaval M (2004). Localization of acid phosphatase activity in the testis of two teleostean species (Oreochromis niloticus and Odonthestes perugiae). Braz. J. Biol. 64: 853-858.

Ribeiro MG and Lima SR (2000). Iniciação às Técnicas de Preparação de Material para Estudo e Pesquisa em Morfologia. SEGRAC Editora e Gráfica Limitada, Belo Horizonte.

Saftig P, Hartmann D, Lullmann-Rauch R, Wolff J, et al. (1997). Mice deficient in lysosomal acid phosphatase develop lysosomal storage in the kidney and central nervous system. J. Biol. Chem. 272: 18628-18635.

Genetics and Molecular Research 9 (2): 620-628 (2010)

CFUNPEC-RP www.funpecrp.com.br 
Sánchez-Pina MA, Rodriguez-Garcia MI and Risueno MC (1980). Localization of the acid phosphatasic activity in plant cell nucleoli. Cell Biol. Int. Rep. 4: 93-104.

Siebert G (1966). Nucleolar enzymes of isolated rat liver nucleoli. Natl. Cancer Inst. Monogr. 23: 285-293.

Soriano RZ and Love R (1971). Electron microscopic demonstration of acid phosphatase in nucleoli and nucleoplasm. Exp. Cell. Res. 65: 467-470.

Sousa M, Moradas FP, Amorim A and Azevedo C (1988). Starfish acrosomal acid phosphatase: a cytochemical and biochemical study. Biol. Cell 63: 101-104.

Stenberg SS (1996). Histology for Pathologists. Lippincott-Raven Publishers, Hong Kong.

Suter A, Everts V, Boyde A, Jones SJ, et al. (2001). Overlapping functions of lysosomal acid phosphatase (LAP) and tartrate-resistant acid phosphatase (Acp5) revealed by doubly deficient mice. Development 128: 4899-4910.

Yousef GM, Diamandis M, Jung K and Diamandis EP (2001). Molecular cloning of a novel human acid phosphatase gene (ACPT) that is highly expressed in the testis. Genomics 74: 385-395.

Zaviacic M (1999). The Human Female Prostate from Vestigial Skene's Paraurethral Glands and Ducts to Woman's Functional Prostate. SAP-Slovak Academic Press, Bratislava. 